\title{
Retraction Note to: The role of seed appendage in improving the adaptation of a species in definite seasons: a case study of Atriplex centralasiatica
}

\author{
Zhaoren Wang ${ }^{2,5 \dagger}$, Yufei Zhao ${ }^{1 \dagger}$, Yuanyuan Zhang ${ }^{4}$, Baoshan Zhao ${ }^{1}$, Zhen'an Yang ${ }^{3 *}$ and Lijia Dong ${ }^{1 *}$
}

\section{Retraction Note to: BMC Plant Biol (2019)19:538}

https://doi.org/10.1186/s12870-019-2090-6

The authors have retracted this article [1] because they did not have permission from the data owner to publish part of the data presented here.

All authors have responded to the correspondence and agree to this retraction.

\footnotetext{
Author details

'School of Life Sciences, Shaoxing University, Shaoxing, Zhejiang, People's Republic of China. ${ }^{2}$ State Key Laboratory of Vegetation and Environmental Change, Institute of Botany, Chinese Academy of Sciences, Beijing, People's Republic of China. ${ }^{3}$ College of Life Science, China West Normal University, Nanchong, Sichuan, People's Republic of China. ${ }^{4}$ College of life science, Shanxi Normal University, Linfen, Shanxi, People's Republic of China. ${ }^{5}$ University of Chinese Academy of Sciences, Beijing, People's Republic of China.
}

Published online: 15 June 2020

\section{Reference}

1. Wang Z, Zhao $Y$, Zhang $Y$, et al. The role of seed appendage in improving the adaptation of a species in definite seasons: a case study of Atriplex centralasiatica. BMC Plant Biol. 2019;19:538 https://doi.org/10.1186/s12870019-2090-6.

\footnotetext{
The original article can be found online at https://doi.org/10.1186/s12870019-2090-6

*Correspondence: Donglijia@126.com; yza2765@126.com

'Zhaoren Wang and Yufei Zhao contributed equally to this work.

${ }^{3}$ College of Life Science, China West Normal University, Nanchong, Sichuan, People's Republic of China

'School of Life Sciences, Shaoxing University, Shaoxing, Zhejiang, People's Republic of China

Full list of author information is available at the end of the article
}

(c) The Author(s). 2020 Open Access This article is licensed under a Creative Commons Attribution 4.0 International License, which permits use, sharing, adaptation, distribution and reproduction in any medium or format, as long as you give appropriate credit to the original author(s) and the source, provide a link to the Creative Commons licence, and indicate if changes were made. The images or other third party material in this article are included in the article's Creative Commons licence, unless indicated otherwise in a credit line to the material. If material is not included in the article's Creative Commons licence and your intended use is not permitted by statutory regulation or exceeds the permitted use, you will need to obtain permission directly from the copyright holder. To view a copy of this licence, visit http://creativecommons.org/licenses/by/4.0/ The Creative Commons Public Domain Dedication waiver (http://creativecommons.org/publicdomain/zero/1.0/) applies to the data made available in this article, unless otherwise stated in a credit line to the data. 